\title{
An Investigation of Students' Entrepreneurial Promotion Difference Across Departments in Higher Education Institutions: The Case of Dire Dawa University
}

\author{
Hailay Aregawi Hagos (MSc.) \\ Lecturer, Dire Dawa University, Department of Banking and finance
}

\begin{abstract}
The basic purpose of this study was to investigate the students' entrepreneurial promotion difference across departments in higher education institutions in the case of Dire Dawa University. More specifically, the study aims to identify the students' entrepreneurship promotion situation, to determine the students' entrepreneurship promotion difference between those who took entrepreneurship course and those who didn't take it as well as among departments. Basically, data were collected using questionnaire from 304 sample respondents which were selected using stratified proportionate random smpling technique. Besides, focus group discussion were made with some selected group of respondents during the questionnaire distribution and colection. Then the collected data were analyzed using frequency, percentage, chi-square analysis techniques as well as narrative analysis. Finally, the result of the study shows that the current entrepreneurship promotion situation of students is low, taking of entrepreneurship course have significant effect on students'entrepreneurship promotion and there is no significant difference on the students' entrepreneurship promotion as a result of college/department difference. Threfore, all students should be given entrepreneurship education using various methods continously at different education levels.
\end{abstract}

Keywords: Students' entrepreneurship promotion, Department, Higher education institution.

DOI: $10.7176 / \mathrm{EJBM} / 11-13-01$

Publication date:May $31^{\text {st }} 2019$

\section{INTRODUCTION}

The term entrepreneurship have been defined and explained by scholars in relation to their respective disciplines overtime. As it is reported in the study by Obino, Namusonge and Sikalieh (2012) the definition of entrepreneurship includes different aspects at different times. In its earliest time, entrepreneurship is defined as the process of bearing the risk of buying at certain prices and selling at uncertain prices. Then after, the definition encompasses the factors of production and conteporarly extends to innovation, creativity and risk taking (Chen, et al, 2010). This time, it is an everyday and a common agenda of all parties like government, organizations, individuals, academicians and others throughout the world (Bygrave \& Hofer, 1991; Zegeye, 2013). Many scholars and organizations (Grieco, 2007; European commission, 2008) have been writing as well as conducting studies on the area of entrepreneurship and forwarding various suggesting issues on it which may help individuals, organizations, governments and the economy of a given country as a whole.

Entrepreneurship is a catalyst for business, innovation, creativity, career development through which it becomes the base for the growing of economy as whole. This time many countries used it as a development strategy in their economic system (Obino, et al., 2012). Providing entrepreneurship education is one of the main motor that produces various work activities in the world. It helps students, employees, self-employed, consultants and other individuals in creating an alternative career option and building confidence that they can set up their own business or social enterprise (Kalimasi, 2010). To this effect, both developed and developing countries are giving series attention to entreprenership program as it can play a great role in their economic growth. It is cosidered as an opportunity for reducing poverty, addressing the unemployment problem, improving innovating activities, providing a positive attitude on the individuals intention to wards the socio-economic aspects and build the overall can-do confidence (Sarkar, 2014). Thus, there is a positive relationship between entrepreneurship and economic growth of a country (Yusuf \& Ismail, 2016).

Based on the alumni survey of higher education institutions in Europe, European Commission (2012) concluded that entrepreneurship education has a positive impact on the entrepreneurial mindset, intentions and their employability of young people, which inturn play a greate role in the society and the economy as a whole. Similarly, Charney, at al, (2000) concluded that on average, entrepreneurship graduates are three times more likely than non-entrepreneurship graduates to start new business ventures. Other studies (Al-mahdi, 2012; Kalimasi, 2010; Koschatzky, 2001; Santos et al, 2012; Zhou \& Xu, 2012; Potter, 2008; European Commission, 2008; Mok, 2010) found a positive relationship between entrepreneurship and students' entrepreneural intantion. This is consistent with the traditional business model that argues not everybody can be entrepreneurial except the few exceptional ones who come from business management (Gibb, 2006)..

On the other hand, As cited in Kalimasi (2010), Gibb (2006) have also developed another theory called 
societal model of entrepreneurship. Unlike to his first model (Traditional Business Model), this model explain entrepreneurship in a wider social environment where by students in different fields of study can be equipped with the entrepreneurial capacity and skills necessary to exploit various opportunities within their professions. In consistent to this theory, Few studies (Oosterbeek, et al, 2008; Hessel et at., 2008) reported that there is insignificant relationship between entrepreneurship program and students' entrepreneurial. Wu (2008) also revealed that the diversity of educational background offered across the various department shows difference on students' entrepreneural perception.

Currently, in Ethiopia the numbers of graduated students are increasing from year to year. On the other hand, the job opportunities that can hold the whole graduated students have been decreasing both at public and private organizations. For this reason, graduate students are required to create a job rather than expecting to be hired in either public or private organizations regardless of their department from which they graduated. Thus, the researcher belief that there is a need to conduct a study to identify whether there is entrepreneurial promotion difference or not among students from different departments.

In addition, the previous studies were focused on either investigating the factors afecting students' entrepreneural intension (Brussels, 2012; Byabashaija, et, al, 2010; Charney et. al, 2000; Hessel et. A1, 2008; Oosterbeek, et. Al, 2008; Negash \& Amentie, 2013; Zegeye, 2013) or investigating the students' entrepreneurial intension and attitude by considering the entreprenuership course in to consideration (Brussels, 2012; Byabashaija, et, al, 2010; Charney et. al, 2000; Hessel et. Al, 2008; Oosterbeek, et. Al, 2008). Some studies (Almahdi, 2012; Kalimasi, 2010; Koschatzky, 2001; Santos et al, 2012; Zhou \& Xu, 2012; Potter, 2008; European Commission, 2008; Mok, 2010) also made study on the role of entrepreneurship education given at higher education on students' entrepreneurship intention and attitude.

Generally, the focus of these studies were on selective departments in which the enterpreneurship is given as a course. That is most of them focuses on the field of technology or/and business and economics. Besides, students who did not take the entrepreneurship course were excluded to study their level of entrepreneurship. That means they ignore the other field of studies that do not incorporate entrepreneurship course in their curriculum. This shows that the previous studies were not an inclusive of students across various field of studies. However, this time in Ethiopia, all graduated students are expected be an entrepreneural regardless of the department from which he/she graduated. Therefore, to fill the specified gap the researcher was motivated to conduct a study with the the following objectives:

1. To describe the entrepreneurship promotion situation of students in the study area.

2. To determine the students' entrepreneurship promotion difference between those who take entrepreneurship course and those who didn't take it.

3. To indicate whether the students' entrepreneurship promotion differ across discipline.

4. To find out the field of study (s) that promotes more students' entrepreneurship.

\section{REVIEW OF RELATED LITERATURE}

\subsection{Overview of Entrepreneurship}

Many scholars define entrepreneurship in respect to their field of study at different times which more or less are related to each other. Entrepreneurship refers to the ability of changing ideas into action that involves creativity, innovation, risk taking, plan and manage projects for achieving objectives (European Commission, 2012). Accrding to Okpara (2000) and QAA (2012) entrepreneurship is defined as the willingness and ability of an individual to identify and successfully use opportunities arround them. Similarly, scholars have also defined the concept of 'entrepreneur' as part of the entrepreneurship. Entrepreneurs are individuals who attempt to predict, implement changes, perceive opportunities and has the motivation, drive and ability to mobilize resources (Knight, 1921; Schumpeter, 1934; Di-Masi, 2010; Reiss, 2010). Pinson (2010) defined an entrepreneur as a person who starts a business by taking risk with a defined vision in order to make money.

Entrepreneurship is the heart of the modern business, improve innovativation and creating incremental wealth so that it considered as a development strategy in many countries (Obino et. at, 2012). There is a diversity of views about what constitutes "entrepreneurship" as a field of study (Gartner, 1990) as well as what constitutes an entrepreneurship program (Wilson, 2008). For instance, In the United States, entrepreneurship is growthoriented ventures or companies, and entrepreneurship programs promote skills for building, financing, and nurturing high-growth companies. In Europe, on the other hand, entrepreneurship is equated with small and medium-sized enterprises, while entrepreneurship programs are training programs that focus promoting the management skills of small business. Hence, the primary purpose of entrepreneurship education at European universities is to develop entrepreneurial capacities and mindsets that support everyone in day-to-day life at home and in society and provide a foundation for entrepreneurs establishing a social or commercial activity (Wilson, 2008). Now a day entrepreneurship is a common to many people, a theamatic area for researchers and academicians, a catalist of economic growth by governments and organizations and generally the agenda of people from different occupations including governments, scholars, educators and policy makers (Obino et. at, 
2012).

\subsection{Theoretical Review}

Various theoretical models that explain the context of entrepreneurship have been developed by different authors over time. Traditional business model is a more specific model that indicates an entrepreneur like a hero addressing entrepreneurship education in the context of business management. This means that not everybody can be entrepreneurial except the few exceptional ones who come from business school (Gibb, 2006). Unlike to his first model (Traditional Business Model), Gibb (2006) have also developed another theory called societal model of entrepreneurship. This model explain entrepreneurship in a wider social environment where by students in different fields of study can be equipped with the entrepreneurial capacity and skills necessary to exploit various opportunities within their professions (Kalimasi, 2010). Integrated Model for Entrepreneurial Performance which is the result of two models: Entrepreneurship Performance (Mathematical) Model and Entrepreneurial Education Model on the other hand, indicates that education for improved entrepreneurial performance is the result facilitators ability, skills and experience; motivation; entrepreneurial skills; business skills and knowledge; the approaches of learning used; and business plan (Pretorious and Nieman, 2005).

There are also many intentional models adopted by different authors over time. One of them is a Shapero's model of an entrepreneurial event. The main argument of Shapero"es model is that the intent to take up an entrepreneurial career is a result of the two perceptions of desirability and feasibility. Where perceptions of desirability refer to the individual's attraction to undertak certain behavior (such as entrepreneurial behavior), while feasibility perceptions refer to the individual's belief in his or her own capacity to carry out certain behavior. The other part of the intentional model is the theory of planned behavior which has been employed in explaining the gradual beginning of entrepreneurial behavior. This theory was created to explain behavior of human beings in different context. The main idea is that intentions may capture motivational factors that influence behavior and that the stronger the intention to engage in behavior the more likely should be its performance (Ajzen, 1991). According to this theory, attitude towards behavior, subjective norms and perceived behavior control are the antecedents of intentions that influence behavior (Ajzen, 1991). Social Cognitive Theory is also the other theory of entrepreneurial intention which provides a framework for understanding and predicting a variety of human behaviour that used for identifying methods in which behaviour might be modified or changed (Bandura, 1986; Pajares, 1997; Ormrod, 1999; Anderson, 2000).

\subsection{Empirical Review}

Oosterbeek, et al (2008) made a study on the impact of entrepreneurship education program on students' entrepreneurship competencies and intentions. In the study, data were collected from two groups: treatment group (291) and from control group (343). Finally, the results show that the program does not have the intended effects: the effect on students' self-assessed entrepreneurial skills is insignificant and the effect on the intention to become an entrepreneur is even significantly negative. Similarly, a study entitled as the effects and impact of entrepreneurship programmes in higher education is done under the European Commission (2012). The study was aimed at determining the effect and impact of entrepreneurship program on four diminsions (competency, intention, employability, and society and economy). Data was gatherd from the almuni report of nine higher education institutions in Europe. The sample respondents includes 1,443 both from control group and treatment group. Finally, the study revealde that Entrepreneurship education has a positive impact on the entrepreneurial mindset of young people, their intentions towards entrepreneurship, their employability and finally on their role in society and the economy.

To investigate the role of higher education institution for entrepreneurship stimulation in regional innovation system in Germany, a study was conducted by Koschatzky (2001). To reach the final result the required data were collected from primary sources through a questionnaire survey of 170 randomly selected respondents for the year 1999 to 2000 . The collected data were analyzed using both descriptive and inferential (OLS model) statistics. Accordingly, the analyzed data indicated that exist programme launched by the federal ministry of education and research has contributed to the stimulation of the establishment of networks and has brought players together who otherwise would not have cooperated by their own.

Zhou \& Xu (2012) made a study with the aim of examining entrepreneurship education as an innovative solution to the challenges facing higher education in China. It first introduces the background for promoting entrepreneurship education in China, analyzes the entrepreneurship education programs and activities in three selected universities, assesses the state of entrepreneurship education both from a student perspective and also through a comparison with developments in the United States, and concludes with recommendations for further developments in entrepreneurship education in China's colleges and universities.

To investigate the role of entrepreneurship education and development on entrepreneurial attitudes and intentions in a developing economy, namely Saudi Arabia a study was conducted by Hassan (2012). He analyzed large, matched datasets gained from surveys of students in Saudi higher educational institutions. Results support 
the proposition that the intention to become self-employed is positively and significantly correlated to the attitudes of the self-employed, certain subjective norms and to the perceived behavioral control. However, after entrepreneurial education, the intention to become self-employed is not positively or significantly correlated with start- up activities. The results do indicate that entrepreneurial education develops entrepreneurial attitudes, intentions, and inspiration of would-be entrepreneurs. These findings contribute to literature on entrepreneurship education and the theory of planned behavior. They will provide useful insights into the state of entrepreneurship education for policy makers in universities and governments in addressing the problem of graduate unemployment particularly in Saudi Arabia.

Brussels (2012) made a study on the area of entrepreneurship program in higher education in Europe with the aim of investigating the impact of entrepreneurship education programmes provided by higher education institutions at four dimensions: competence, intentions towards entrepreneurship, employability and society and the economy. The data were collected through questionnaire using online survey from those who participated in entrepreneurship programmes as well as surveying a comparable control group consisting of alumni that have not participated in entrepreneurship programmes from nine European universities. The collected data were analyzed descriptively with the application of SPSS software. Finally, the study revealed that entrepreneurship education has a positive impact on the entrepreneurial mindset of young people, their intentions towards entrepreneurship, their employability and finally on their role in society and the economy. These are the major results of this study among alumni of higher education institutions in Europe.

A research intends to analyze how Universities must have an important role in social entrepreneurship promotion and in the regional and social sustainable development itself. In fact, it's our opinion that students must be advised how can they start up their professional careers in social area and how they can be competitive in the professional world. Thus, academic curricula and teaching methodologies must give them the basic tools so they can have entrepreneurial spirit and to develop innovative programmers/organizations as well as, at the same time, to contribute for a more inclusive society (Santos, Guedes, \& Fonseca, 2012).

In their study, based on a longitudinal study (1985-1999) covering 2,484 participants, 2,024 non entrepreneurship and 460 entrepreneurship graduates with the intent of assessing the effect of the Berger Entrepreneurship Program at the University of Arizona on graduates by comparing them with a matched sample of non - entrepreneurship University of Arizona business graduates from 1985 through 1998, Charney et al. (2000) found that entrepreneurship education contributes to risk- taking and the formation of new ventures, increases the propensity of graduates to be self- employed, job satisfied, income of graduates and growth.

Hessel et at. (2008) also conducted a study to investigate the impact of the program in a Dutch college using an instrumental variables approach in a difference-in-differences framework. The results show that the program does not have the intended effects: students' self-assessed entrepreneurial skills remain unaffected and students' intentions to become an entrepreneur even decrease significantly. Yi et al. (2014) made a study on the investigation of the practice of entrepreneurship education in University Malaysia Perlis and perception of students on entrepreneurship education. Primary data are collected to reveal students' perceptions toward entrepreneurship education. The results show that the performance of entrepreneurship education in University Malaysia Perlis was favorable and recognized by students.

On the other hand, Byabashaija et al. (2010) made an investigation to assess the impact of entrepreneurial education and societal subjective norms on entrepreneurial attitudes and intentions to start a business of university students in Uganda. Data were collected in two waves: Wave I before the entrepreneurship course and Wave II after the entrepreneurship course (four months later). Analyses included tests of significance of changes in the attitudes and intentions of students after the entrepreneurship course and the mediating role of attitudes and moderating role of employment expectations. The results show small but significant changes in attitudes and a significant mediating role of attitudes perceived feasibility and perceived desirability but non- significant role of perceived feasibility on the relationship between societal subjective norms and entrepreneurial intentions. Contrary to expectation the study did not find evidence to support a moderating influence of employment expectations on the relationship between the attitude variables and entrepreneurial intentions. There are lessons to be learnt for policy makers and more questions for researchers.

A study also conducted by Negash \& Amentie (2013) on the investigation of determinants of higher education students' entrepreneurial intention in four selected Ethiopian Universities (Jimma, Addis Ababa, Adama and Haramaya). Survey research method was employed involving total of 210 students from four public Universities found in the Ethiopia. Sample of respondents from four selected Universities (Jimma, Addis Ababa, Adama, and Haramaya) were drawn by using systematic sampling techniques. The study used both primary and secondary data. Regression analysis was used to explain the effect of independent variables on a dependent variable. Additionally mean scores and standard deviations were calculated to identify the most important factors that determine students Entrepreneurial intentions in the selected Universities. The study proposes five factors contributing to the development of entrepreneurial intention in selected universities. Accordingly, subjective norms, perceived self efficacy, university environment, perceived educational support and students attitude 
toward entrepreneurship were significant determinants for entrepreneurial intention in selected public universities.

Zegeye (2013) conducted a study on similar topic in Wollo University, Ethiopia with the aim of investigating the inclination towards entrepreneurship among university students in Ethiopia. Data were collected from 400 randomly selected graduate students found in five departments of business and Economics College using questionnaire. Descriptive analysis, a principle axis oblique factor analysis and hierarchical multiple regression were performed to examine the hypothesized propositions. Finally, The results of the analyses indicated that two entrepreneurship education variables, i.e. the university's role to promote entrepreneurship and the entrepreneurial curriculum and content along with gender, working experience and mother's occupation are statistically significant.

\section{RESEARCH METHODOLOGY}

\subsection{Research Design}

In the study qualitative research approach was applied. Accordingly, qualitative data were collected on a crosssectional research basis. Besides, the type of research employed under this study was both descriptive and explanatory researches. It describes the existing entrepreneurship promotion level of students and identifies the deparment that more promotes students' entrepreneurship. It also tried to show the effect of taking entrepreneurship course as well as department difference on students' entrepreneurship promotion.

\subsection{Data Type, Source and Method of Data Collection}

In this study a firsthand qualitative data were collected using primary sources including questionnaire and focused group discussions.

Questionnaire: both close ended and open ended structured questionnaires were prepared and personally distributed by the enumerators for the respondents (students). In the questionnaire a detail questions were included in line to the basic research questions.

Focused group discussion: in support to the questionnaire, focused group discussions were also made with some selected student respondents on the basic research questions.

\subsection{Target Population and Sampling Design}

The target population of the study includes students engaged in various departments of the selected University. To get sufficient and reliable data, the study was incorporated only those students who are at the graduating year. Accordingly, based on the data obtained from Registrar and Alumni office (2016), there were a total of 2,057 students who graduates in 2016. From this a sample of 335 were selected by applying a simplified scientific

formula provided by yemane (1997) i.e. $n=\frac{N}{1+N(e) 2}$ in which e is the level of precision at $5 \%$ level of significance. That is:

$$
n=\frac{N}{1+N(e) 2}=\frac{2,057}{1+2,057(0.05) 2}=\frac{2,057}{1+5.1425}=\frac{2,057}{6.1425}=335
$$

To avoid the biasness of results occured by concentrating in few selected departments and to generate more accurate results by giving the chance to be included each respondents from various departments, the study incorporated different departments of the university. Thus, to select the sample size form each department, stratified random sampling technique was applied. With this technique, the sampling frame was organized in to relatively homogeneous groups or stratum (i.e. based on the departments). Then by applying the simple random sampling technique, the total sample was selected from each stratum (department) proportionally (that is, total sample size/total population*department size). Accordingly, the respective sample size from each department is given below: 
Table 1: The proportional sample size of each department from three University

\begin{tabular}{|c|c|c|c|}
\hline \multirow{2}{*}{ Code } & \multirow[t]{2}{*}{ College/Department } & \multicolumn{2}{|c|}{ Dire Dawa University } \\
\hline & & \begin{tabular}{|l|} 
Total population \\
\end{tabular} & Sample size \\
\hline 2 & College of business and economics & & \\
\hline 21 & Accounting & 90 & 15 \\
\hline 22 & Banking & 50 & 8 \\
\hline 23 & Economics & 87 & 14 \\
\hline 24 & Marketing & 55 & 9 \\
\hline 25 & Management & 91 & 15 \\
\hline 26 & LSCM & 39 & 6 \\
\hline 27 & PADM & 82 & 14 \\
\hline 3 & Institute of technology & & \\
\hline 31 & Architecture & 37 & 6 \\
\hline 32 & Civil Engineering & 138 & 23 \\
\hline 33 & Chemical engineering & 53 & 9 \\
\hline 34 & CTM & 119 & 20 \\
\hline 35 & Electrical Engineering & 104 & 17 \\
\hline 36 & Mechanical Engineering & 62 & 10 \\
\hline 37 & Industrial engineering & 44 & 7 \\
\hline 38 & Surveying engineering & 123 & 20 \\
\hline 39 & Textile engineering & 50 & 8 \\
\hline 40 & Computer science & 51 & 8 \\
\hline 4 & College of natural science & & \\
\hline 41 & Biology & 124 & 20 \\
\hline 42 & Chemistry & 107 & 18 \\
\hline 43 & Mathematics & 99 & 16 \\
\hline 44 & Physics & 80 & 13 \\
\hline 45 & Sport Science & 51 & 8 \\
\hline 46 & Statistics & 100 & 16 \\
\hline 5 & College of social science & & \\
\hline 51 & Amharic & 21 & 3 \\
\hline 52 & English & 21 & 3 \\
\hline 53 & Geography & 41 & 7 \\
\hline 54 & History & 29 & 5 \\
\hline 55 & Political science & 26 & 4 \\
\hline 56 & Psychology & 31 & 5 \\
\hline 6 & College of law & & \\
\hline 61 & Law & 52 & 8 \\
\hline & Total & 2,057 & 335 \\
\hline
\end{tabular}

\subsection{Method of Data Analysis}

After collecting the raw data, the next activity is processing of them through checking and editing to detect errors and omissions; coding and classifying based on common characteristics of variables; and entering to Microsoft office excel to make ready for analysis and discussions. The processed data were analyzed using both descriptive and inferential statistical tools. In line to the specific objectives, the collected data were initially analyzed using descriptive analysis techniques such as frequency distribution and statistical measures. Besides, descriptive narration through concurrent triangulation strategy was applied for analyzing the data collected from focus group discussions. Beyond the descriptive analysis, an inferential analysis tool (Ch-square test) were used particularly to test the relationship between the dependent and independent variables and to draw conclusions. Stata, version 11.2 software was used to run the result of the statistical result.

\section{RESULT AND DISCUSSION}

\subsection{Introduction}

As it is given in the objective part of the paper, the main aim of the study was to investigate the students' entrepreneural promotion difference across departments: the case of Dire Dawa University. In line to each specific objective, data were collected using questionnaire and focus group discussion methods. With regard to the first method (i.e. questionnaire), 335 questionnaires were distributed to respondents by the enumerators. 
However, at the time of counting and checking the collected questionnaires, 31 questionnaires were found unreturned and incompelete due to different reasons. This shows that 31 (9.25 percent) questionnaires were excluded from the analysis which shows the response rate of 89.75 percent. Besides, data were collected using focus group discussions with some selected students at the time of questionnaire distribution and collection. Therefore, data were analyzed based on the data collected using questionnaires from 304 respondents as well as data collected through focus group discussions.

\subsection{Entrepreneurship Background of Respondents}

As a background information, respondents were required to state opinion on their lower clases' entrepreneurship background. Accordingly, they were asked whether they took the entrepreneurship topic in their lower classes and the way they took it. The response to each issue is summarized in the below table using frequency distribution.

Table 2 Respondents' Entrepreneurship Background

\begin{tabular}{|l|l|l|l|l|}
\hline No. & Variable & Category & \multicolumn{2}{l|}{ Frequency Distribution } \\
\cline { 4 - 5 } & & & No. & Percent (\%) \\
\hline \multirow{2}{*}{1} & \multirow{2}{*}{ Entrepreneurship education at lower school } & Yes & 95 & 31 \\
\cline { 3 - 5 } & & No & 209 & 69 \\
\cline { 3 - 5 } & & Total & 304 & 100 \\
\hline 2 & \multirow{2}{*}{ Way of taking Entrepreneurship education } & As a course & 5 & 5 \\
\cline { 3 - 5 } & & As a chapter & 17 & 18 \\
\cline { 3 - 5 } & & As a topic/sub-topic & 73 & 78 \\
\cline { 3 - 5 } & & Total & 95 & 100 \\
\hline 3 & Practical based & Yes & 61 & 20 \\
\cline { 3 - 5 } & & No & 243 & 80 \\
\cline { 3 - 5 } & & Total & 304 & 100 \\
\hline
\end{tabular}

Source: Own survey (2016)

As it is depicted in table 2, item one, respondents were asked that "Did you learn entrepreneurship before joining your university education (i.e. at primary and/or secondary school)"? In response, most (69 percent) of them were said "No", while the remaining 31 percent of them were said "Yes". Besides, for those who said "Yes" another question (If your answer for question number one is "Yes", how you took it?) were asked so as to know the means in which they were taken it. Accordingly, most (78 percent) of them were said "as a topic/subtopic", whereas the remaining 18 percent and 5 percent of them said "as a chapter" and "as a course" respectively. This implies that few students tooke entrepreneurship in the form of topic/sub-topic and others in the form of chapter. Furthermore, to understand the respondents' entrepreneurship background, they were also requested that "Had your primary and secondary education practical based"? In response, most (80 percent) of them said "No" and the remaining 20 percent said "Yes". This shows that students at primary and secondary school were not learn the courses practically. Thus, it is possible to conclude that the entrepreneurship background of students (i.e. entrepreneurship at primary and secondary education) is weak.

\subsection{Students' Entrepreneurship Promotion Situation}

As it is stated in the objective part of the paper, the first objective of the study is idntifying of students' entrepreneurship promotion situation as a result of university education in their respective department. In doing so, respondents were requared to state their entrepreneurship promotion level based on three interrelated nominal and ordinal scale of measurments. The first measure is based on "Yes or No" responses (nominal scale). The other two ways were ordinal likert scales which are "high, medium or low" and "highly promoted, promoted, undecided, low promoted and very low promoted". With regard to the first measurement, respondents (students) were required to response their level of entrepreneurship promotion as a result of university education on either "Yes or No" basis. They were also requested to measure their level of entrepreneurship promotion on three point likert scale (High, Medium or Low) basis. Besides, they were required to report their promotion level on five point likert scale (highly promoted, promoted, undecided, low promoted and very low promoted). The response to each of the three indicators is given in the below table (table 3). 
Table 3 Students' entrepreneurship promotion situation

\begin{tabular}{|c|c|c|c|c|}
\hline \multirow[t]{2}{*}{ No. } & \multirow[t]{2}{*}{ Variable } & \multirow[t]{2}{*}{ Category } & \multicolumn{2}{|c|}{ Frequency Distribution } \\
\hline & & & Number & Percent (\%) \\
\hline \multirow[t]{3}{*}{1} & \multirow[t]{3}{*}{ Entrepreneurship promotion } & Yes & 89 & 29 \\
\hline & & No & 215 & 71 \\
\hline & & Total & 304 & 100 \\
\hline \multirow[t]{4}{*}{2} & \multirow[t]{4}{*}{ Entrepreneurship promotion level } & High & 36 & 12 \\
\hline & & Medium & 69 & 23 \\
\hline & & Low & 199 & 65 \\
\hline & & Total & 304 & 100 \\
\hline \multirow[t]{6}{*}{3} & \multirow[t]{6}{*}{ Rate of entrepreneurship promotion } & Highly promoted & 26 & 9 \\
\hline & & Promoted & 28 & 9 \\
\hline & & Undecided & 44 & 14 \\
\hline & & Low promoted & 133 & 44 \\
\hline & & Very low promoted & 73 & 24 \\
\hline & & Total & 304 & 100 \\
\hline
\end{tabular}

Source: Own survey (2016)

As it is shown in table 3, item 1, respondents (students) were required to state their entrepreneurship promotion as a result of their university education on a "Yes or No" basis. In doing so, majority (71 percent) of them were said No, whereas the remaining 29 percent were agreed that university education helps them on promoting their entrepreneurship. As it is indicated in the same table, item 2, respondents were also asked to report their entrepreneurship promotion level on three point likert skale (High, Medium or Low). Accordingly, most (65 percent) of them were evaluated their entrepreneurship promotion level as low. While the remaining 23 percent and 12 percent were evaluated as medium and high respectively. Besides, respondents were requested to indicate their entrepreneurship promotion level on five point likert skale (highly promoted, promoted, undecided, low promoted and very low promoted). In response, 44, 24, 14, 9 and 9 percent of the respondents were replied as low promoted, very low promoted, undecided, promoted and highly promoted respectively.

In addition, focus group discussions were made in relation to the students' entrepreneurship promotion level. Participants of the focus group were therefore required to discuss on the students' entrepreneurship promotion level as a result of university education. In response, most of the respondents reflect that their entrepreneurship level is not promoted. They said that "we take the courses including entrepreneurship and we score any grade point otherwise nothing is added to our entrepreneurship promotion as a result of these courses". Some students were also report that they were not taken the course entrepreneurship. Thus, it is possible to conclude that the students' entrepreneurship promotion level (which is measured based on the above variables) is low.

\subsection{Effect of entrepreneurship course on Students' Entrepreneurship Promotion}

This is also a second objective of the study which stated in the objective part as: determining of the students' entrepreneurship promotion difference between those who take entreprenership course and those who did't take it. In line to this, respondents were required to state whether they have taken an entrepreneurship course or not. To this effect, almost half (51 percent) of the respondents were taken the course entrepreneurship and the remaining (49 percent) were not taken the course. Again to explain the effect of entrepreneurship course on students' entrepreneurship promotion, the result is run in relation to their entrepreneurship promotion level. Table 4 summarizes the respondents' response to each variable and its effect on students' entrepreneurship promotion.

Table 4: Students' entrepreneurship promotion in relation to Entrepreneurship course

\begin{tabular}{|c|c|c|c|c|c|c|c|c|}
\hline \multirow[b]{2}{*}{ Variable } & \multirow[b]{2}{*}{ Category } & \multicolumn{2}{|c|}{ Observation } & \multicolumn{3}{|c|}{ Entrepreneurship Promotion } & \multirow[b]{2}{*}{$\mathrm{Chi}^{2}$} & \multirow[b]{2}{*}{ P-value } \\
\hline & & No. & $\%$ & High & Medium & Low & & \\
\hline \multirow{3}{*}{ Taking entrepreneurship course } & Yes & 155 & 51 & 30 & 29 & 96 & \multirow{3}{*}{5.63} & \multirow[t]{3}{*}{0.06} \\
\hline & No & 149 & 49 & 16 & 39 & 94 & & \\
\hline & Total & 304 & 100 & 46 & 68 & 190 & & \\
\hline
\end{tabular}

Source: Own survey (2016)

As it is seen in the above table, 30, 29, and 96 of those respondents who took entrepreneurship course were said high, medium and low on their entrepreneurship promotion. On the other hand, 16, 39, and 94 of those respondents who didn't take entrepreneurship course were said high, medium and low on their entrepreneurship promotion. This shows that there is a positive relationship between taking of entrepreneurship course and students' entrepreneurship promotion. For instance, when we compare the respondents who said "high" 30 of them were taken the course and 16 of them were not taken it. Furthermore, the Chi-square analysis $\left(\mathrm{Chi}^{2}=5.63\right.$, 
$\mathrm{P}=0.060$ ) shows that there is a significant association between taking entrepreneurship and entrepreneurship promotion at 10 percent significance level. This implies that taking of entrepreneurship course have significant effect on students' entrepreneurship promotion. The result of the study is consistent with some studies (Hassan, 2012; Brussels, 2012; Charney et al., 2000; Yi et al., 2014; Negash \& Amentie, 2013; Mekonnin, 2015; Aschalew, 2016) that concluded that entrepreneurship education has a positive impact on the entrepreneurial mindset of young people, their intentions towards entrepreneurship, their employability and finally on their role in society and the economy. On the other hand, it is inconsistent with few studies (Arenius et. al, 2004; Oosterbeek et al., 2008; Hessel et at., 2008) that reported the program does not have the intended effect on students' self-assessed entrepreneurial skills.

\subsection{Students' Entrepreneurship Promotion across College/Department}

Assessing whether there is difference on students' entrepreneurship promotion level across department as well as identifying the department that more promotes students' entrepreneurship promotion (if so) were the third and fourth objectives of the study. In doing so, respondents (students) were required to state their department and their respective entrepreneurship promotion level on the distributed questionnaire. a sample of students from 30 departments under different colleges were incorporated. Then their entrepreneurship promotion level were measured based on their respective responses to the three point likert scale in reference to their department as well as college. Table 5 and 6 summarizes the overall distribution of the students across the 30 departments as well as the 5 colleges and their entrepreneurship promotion level.

Table 5: Students' Entrepreneurship Promotion across College

\begin{tabular}{|c|c|c|c|c|c|c|c|}
\hline \multirow[b]{2}{*}{ College } & \multicolumn{2}{|c|}{ Observation } & \multicolumn{3}{|c|}{ Entrepreneurship Promotion } & \multirow[b]{2}{*}{$\mathrm{Chi}^{2}$} & \multirow[b]{2}{*}{ P-value } \\
\hline & No. & $\%$ & High & Medium & Low & & \\
\hline Business \& economics & 75 & 24.7 & 17 & 13 & 45 & \multirow{6}{*}{9.55} & \multirow{6}{*}{0.298} \\
\hline Institute of Technology & 119 & 39.15 & 18 & 26 & 75 & & \\
\hline Natural science & 78 & 25.65 & 7 & 24 & 47 & & \\
\hline Social science & 24 & 7.9 & 3 & 4 & 17 & & \\
\hline Law & 8 & 2.6 & 1 & 1 & 6 & & \\
\hline Total & 304 & 100 & 46 & 68 & 190 & & \\
\hline
\end{tabular}

Source: Own survey (2016)

Table 6: Students' Entrepreneurship Promotion across Department

\begin{tabular}{|l|l|l|l|l|l|l|}
\hline \multirow{2}{*}{\multicolumn{1}{c|}{ Department }} & \multicolumn{1}{c|}{ Observation } & \multicolumn{2}{c|}{ Entrepreneurship Promotion } & \multirow{2}{*}{ Chi $^{2}$} & P-value \\
\cline { 2 - 6 } & No. & \% & High & Medium & Low & \\
\hline Accounting & 14 & 4.61 & 4 & 1 & 9 & 5 \\
\hline Banking & 7 & 2.30 & 1 & 1 & 7 \\
\hline Economics & 13 & 4.28 & 4 & 2 & 4 \\
\hline Marketing & 9 & 2.96 & 2 & 3 & 9 \\
\hline Management & 15 & 4.93 & 3 & 3 & 5 \\
\hline LSCM & 5 & 1.64 & 0 & 0 & 6 \\
\hline PADM & 12 & 3.95 & 3 & 3 & 4 \\
\hline Architecture & 6 & 1.97 & 2 & 0 & 14 \\
\hline Civil & 23 & 7.57 & 3 & 6 & 5 \\
\hline Chemical & 9 & 2.96 & 2 & 2 & 13 \\
\hline CTM & 15 & 4.93 & 1 & 1 & 9 \\
\hline Electrical & 16 & 5.26 & 2 & 5 & 2 \\
\hline Mechanical & 10 & 3.29 & 1 & 7 & 5 \\
\hline Industrial & 7 & 2.30 & 1 & 1 & 13 \\
\hline Surveying & 17 & 5.59 & 2 & 2 & 6 \\
\hline Textile & 8 & 2.63 & 2 & 0 & 4 \\
\hline Computer & 8 & 2.63 & 2 & 2 & 10 \\
\hline Biology & 16 & 5.26 & 1 & 5 & 10 \\
\hline Chemistry & 18 & 5.92 & 3 & 5 & 9 \\
\hline Mathematics & 13 & 4.28 & 0 & 4 & 5 \\
\hline Physics & 7 & 2.30 & 0 & 2 & 6 \\
\hline Sport & 8 & 2.63 & 1 & 1 & 7 \\
\hline Statistics & 16 & 5.26 & 2 & 7 & $\mathbf{0}$ \\
\hline Amharic & 3 & 0.99 & 1 & 1 & 3 \\
\hline English & 3 & 0.99 & 0 & 0 & \\
\hline
\end{tabular}




\begin{tabular}{|c|c|c|c|c|c|c|c|}
\hline \multirow[b]{2}{*}{ Department } & \multicolumn{2}{|c|}{ Observation } & \multicolumn{3}{|c|}{ Entrepreneurship Promotion } & \multirow[b]{2}{*}{$\mathrm{Chi}^{2}$} & \multirow[b]{2}{*}{ P-value } \\
\hline & No. & $\%$ & High & Medium & Low & & \\
\hline Geography & 7 & 2.30 & 1 & 2 & 4 & & \\
\hline History & 5 & 1.64 & 1 & 1 & 3 & & \\
\hline Political & 3 & 0.99 & 0 & 0 & 3 & & \\
\hline Psychology & 3 & 0.99 & 0 & 0 & 3 & & \\
\hline Law & 8 & 2.63 & 1 & 1 & 6 & & \\
\hline Total & 304 & 100 & 36 & 69 & 199 & & \\
\hline
\end{tabular}

Source: Own survey (2016)

As indicated in the above table (table 5 and 6$)$, most (119 or 39.13\%) of the respondents (students) comes from 10 departments of institute of technology. Specifically, 6, 23, 9, 15, 16, 10, 7, 17, 8 and 8 of the respondents (students) come from architecture, civil, chemical, CTM, electrical, mechanical, Industrial, surveying, textile and computer engineering departments respectively. In contrast, based on the survey, college of law constitutes the smallest ( 8 or $2.63 \%$ ) number of respondents (students) which comes from one department called "department of law". The remaining $78(25.66 \%), 75(24.67 \%)$ and $24(7.89 \%)$ of the students (respondents) comes from college of natural science, college of business and economics and college of social science respectively. These were also come from different departments within each college (see table 5).

Table 5 also depicts the students' entrepreneurship promotion level across colleges as well as departments in three point likert scale. With regard to the general students' entrepreneurship promotion, most (190) of the students (respondents) were replaid low, while the remaing 46 and 68 of them were said high and medium respectively.

When we look at the students' entrepreneurship promotion level across colleges, there seems slite difference among the students' entrepreneurship promotion. For instance, 17 (22.67 percent) of the students from college of business and economics shows high entrepreneurship promotion which followed by students who come from institute of technology, college of law, college of social science and college of natural science which constitutes 18 (15 percent), 1 (12.5 percent), 3 (12.5 percent) and 7 ( 9 percent) respectively. In other words, 6 (75\%), $17(70 \%), 75(63 \%), 47(60 \%)$ and $45(60 \%)$ of the students from college of law, college of social science, institute of technology, college of natural science and college of business and economics shows low entreprenership promotion respectively. This descriptive result indicates larger students from college of business and economics shows slitly high entreprenership promotion which follws by students from institute of technology. On the other hand, larger students from college of law shows low entrepreneurship promotion which follows by students from college of social science.

However, the association between students' college deference and their respective entrepreneurship promotion is not statistically significant according to the Pearson chi-square test statistics $\left(\mathrm{Chi}^{2}=9.55, \mathrm{P}=0.298\right)$. Thus, from this result it is possible to conclude that there is no difference in terms of students' entrepreneurship promotion accross their college although the descriptive statistical result shows a slight difference among students from different colleges.

In relation to the students' entrepreneurship promotion across departments, there is no clear difference on the scale of students' entrepreneurship promotion. students from each department showed similar and inconsistent promotion scale (see table 6). In addition, the determined Pearson chi $2\left(\mathrm{Chi}^{2}=55.47, \mathrm{P}=0.57\right)$ indicated that there is no association beteween the students' entrepreneurship promotion and their respective departments. Thus, like the college difference, there is no clear difference on the students' entrepreneurship promotion as a result of department difference which in turn difficult to identify the department which more promotes students' entrepreneurship promotion.

\subsection{College/Department that Promotes Students' Entrepreneurship More}

This was the last objective of the study that comes once the result of the third objective is found. Even though some descriptive statistics indicates higher or lower value for some college/department, the Pearso chi2 result reveals that there is no association between the two variables. This implies that there is no statistically significant association between the students' entrepreneurship promotion and their college/department. In addition, focus group discussions were also made to describe whether there is difference on students' entrepreneurship promotion level across department as well as identifying the department that more promotes students' entrepreneurship promotion (if so). In the discussions respondents (students) were highly debated especially with the first issue (i.e. whether there is difference on students' entrepreneurship promotion level as a result of department difference). Some of them supports the existence of difference among students from different department with the justification that some departments offer entrepreneurship course and the nature of the department is easy to convert to real world. However, many respondents disagreed with the difference with the following justifications:

- The existing entrepreneurs that we observe come from different professions, lower classes and even 
there are many illiterate entrepreneurs.

- Entrepreneurship can be promoted through trainings, experiences, workshops, seminars and other activities.

- If someone takes the initiative through different mechanisms, he/she can be an entrepreneur regardless of his/ her field of studies.

In general, from the above discussions, we can conclude the following two points. First, even if there were some opinions that show difference on students' entrepreneurship promotion among college as well as department, most of the respondents' opinion did not support the idea of students' entrepreneurship promotion among college/department with reasonable justifications. Second, the above arguments indicated that identify the department which more promotes students' entrepreneurship promotion was impossible. Hence, the survey of the study showed that there is no clear difference on the students' entrepreneurship promotion as a result of department difference so that one department cannot be more or less promotes students' entrepreneurship promotion.

\section{CONCLUSION AND RECOMMENDATION}

\section{Conclusion}

Although some respondents were agreed with the provision of entrepreneurship program in their lower clases (primary and secondary education) in the form of either topic/sub-topic or chapter, most of them were not agree on this. Besides, their lowere clsses course delivery approache was not practical based. Thus it is possible to conclude that the entrepreneurship background of students at lower classes (primary and secondary education) is weak. In relation to the students' entrepreneurship promotion as a result of their university education, most of the surveyed respondents replied low entreprenership promotion level. This shows that the university is not exerting effort on promoting its students entreprenership through the provision of education.

The result of the study also revealed that taking of entrepreneurship course have significant factor on students' entrepreneurship promotion. This can infere that students who take the course entrepreneurship have high probability of promoting their entrepreneurship than those who didn't take that course. Based on the survey of this study, college/department was found insignificant factor on affecting the students' entrepreneurship promotion. That is the students' entrepreneurship promotion scale is similar regardless of their field of study. This shows that the field of study at which a student learn could not vary their entrepreneurship promotion scale. Hence, the survey of the study showed that there is no clear difference on the students' entrepreneurship promotion as a result of college/department difference so that one department cannot be promotes students' entrepreneurship more or less than any other.

\section{Recommendation}

In Ethiopia the higher education institutions have been expanding both in size and outreach to people. They produce thousands of graduates each year. Despite of the expansions of universities and increment of graduate students, unemployment is high and is one of the socio economic problems in the country. There are many graduated students who are waiting to be hired in different public and private organizations. Besides, the finding of this study indicated that the scale of the students' entrepreneurship promotion was low. Proper understanding of these problems constitute an important and essential starting point for the government in general and higher education institutions in particular on what sorts of policies and strategies might be undertaken to solve the problem. Thus, on the basis of the findings and conclusions made, in this study the following recommendations were forwarded:

* Entrepreneurship programs should be given at primary and high school classes in terms of topic and other forms such as an entrepreneurship clubs and teachers should provide entrepreneurship ideas to their students in class. Besides, wide and continuing motivational programs should be arranged for entrepreneurial students.

* Higher education institutions should provide different entrepreneurship programs that promote students entrepreneurship skill. They should establish and strengthen an incubation center that facilitates and promote entrepreneurship activities for students. They should begin an entrepreneurship clubs, day, week. Other programs such as motivation, workshop, guest lecture and experience sharing should be arranged.

* To increase the importance of taking entrepreneurship course on promoting students' entrepreneurship, higher education institutions should give emphasis on the way of delivering the course and expand to all programs. Students should be given trainings, guest lectures and experience of entrepreneurs while they are teaching that course as well as they should be assessed on more practical way.

* Finally, policy makers in general and higher education institutions in particular should design a policy that students continuously applied in line to their regular teaching learning process. Students should be given guidelines that can motivate them to cooperate, save capital and generate idea while they are in 
campus so that they will directly convert their idea in to practice once they graduated.

REFERENCE

Ajzen, I. (1991). The Theory of Planned Behaviour, Organizational Behaviour and Human Decision Processes, (50), 179-211.

Al-mahdi, H. (2012). The role of higher education in promoting entrepreneurship education in Saudi Arabia.

Anderson, A. (2000) Paradox in the Periphery: an entrepreneurial reconstruction, entrepreneurship and Regional Development, 12, 91-109.

Arenius, P. (2004), "Women in Entrepreneurship". The Entrepreneurial intentions: Some approaches and empirical evidence. European Journal of Work and Organizational Psychology.

Bandura, A. (1986) Social foundation of thought and action: A social cognitive theory. Englewood Cliffs, NJ: Prentice Hall, 2:63-93

Brussels (2012). Effects and impact of entrepreneurship programmes in higher education, Entrepreneurship Unit Directorate-General for Enterprise and Industry, European Commission

Byabashaija, W., Isaac Katono, I., \& Robert Isabalija, R. (2010).The Impact of College Entrepreneurial Education on Entrepreneurial Attitudes and Intention to Start a Business in Uganda.

Charney, A., Libecap, G., and Eller, K. (2000). The impact of entrepreneurship education: an evaluation of the Berger entrepreneurship program at the University of Arizona. University of Arizona.

Chen, W., Weng, C., and Hsu, H. (2010). A study of the entrepreneurship of Taiwanese youth by the Chinese Entrepreneur Aptitude Scales. Journal of Technology management in China, Vol.5 No.1. Emerald Group Publishing.

Di-Masi, Paul (2010). "Defining Entrepreneurship".

European Commission (2008). Effects and impacts of entrepreneurship programs in higher education, entrepreneurship unit, Brussels.

Gartner, W. B. (1998). Who is an entrepreneur? 'America small Business journal.

Grieco, D. (2007). The entrepreneurial decision: theories, determinants and constraints. Liuc Papers n. 207, Serie Economia e Impresa, 54

Hassan, A. (2012). The role of higher education in promoting entrepreneurship education in Saudi Arabia. Brunel Business School, Doctoral Symposium

Hessel, O., van, M., and Auke, I. (2008). The impact of entrepreneurship education on entrepreneurship competencies and intentions: An evaluation of the Junior Achievement Student Mini-Company Program. Jena economic research papers.

Kalimasi, P. (2010). Role of higher education in promoting entrepreneurship education across disciplines in Tanzania. Mzumbe University, Morogoro.

Knight, F. (1921) Evolution of Entrepreneurship".

Koschatzky, K. (2001). The role of higher education institutions for entrepreneurship stimulation in regional innovation systems: Evidence from the network-oriented "EXIST promotion of university based startups" programme in Germany, institute systems and innovation research ISSN 1438-9843.

Mok, K. H. (2010). Innovation and education: A comparative study of five Asian societies. Hong Kong Institute of Education, China.

Negash, E. \& Amentie, CH. (2013). An investigation of higher education student's entrepreneurial intention in Ethiopian Universities: Technology and business fields in focus. Department of Management, Jimma University Jimma, Ethiopia.

Obino, A., Mary, N., and Damary, S. (2012). The Concept of Entrepreneurship: in pursuit of a Universally Acceptable Definition; International Journal of Arts and Commerce, Vol. 1 No. 6

Okpara, I. O. (2000). Entrepreurship; Precious printers and publishers, Enugu.

Oosterbeek, H., Van, M., and Ijsselstein, A. (2008). The impact of entrepreneurship education on entrepreneurship competencies and intentions: An evaluation of the Junior Achievement Student MiniCompany Program. ISSN 1864-7057

Ormrod, J.E. (1999) Human Learning (3rd Edition), Upper Saddle River, NJ: Merrill Prentice Hall.

Pajares, F. (1997) Current directions in self-efficacy research. In M. Maehr and P. Pintrich (eds.), Advances in motivation and achievement, 10, 1-49. JAI Press.

Potter, J. (2008). Entrepreneurship and higher education: local economic and employment development.

Quality Assurance Agency (QAA), (2012). Enterprise and entrepreneurship eduction: Guidance for UK higher education providers.

Reiss, B. (2010). "Entrepreneur: What's In a Definition?

Santos, A. Guedes, and M. Fonseca (2012). The role of teaching institutions to prepare and promote social entrepreneurs. ACRN Journal of entrepreneurship perspectives 1(1) p. 161-167, ISSN 2224-9729.

Sarkar, S. (2014). International Journal of Finance and Policy Analysis. London: Universal Publishers.

Wilson, K. Chapter 5: Entrepreneurship education in Europe. In Entrepreneurship and Higher Education; Potter, 
J.E, Ed; OECD Publishing: Paris, France, 2008; pp. 98-115. Entrepreneurship in higher education, especially within non-business studies, 2008. European Commission Web site.

Wu.S, and Wu, L. (2008). The impact of higher education on entrepreneurial intentions of university students in China. Journal of Small Business and Enterprise Development Vol.15, No.4.

Yusuf, N. And Ismail, N. A. (2016). The role of entrepreneurship in economic development in Saudi Arabia. International Journal of Business and Economic Developmen, Volum 4 Number 1.

Zegeye, B. (2013). Factors Explaining Students' Inclination towards Entrepreneurship: Empirical Study of Ethiopian University Students; Journal of Emerging Issues in Economics, Finance and Banking (JEIEFB), An Online International Monthly Journal (ISSN: 2306 367X); Volume:1 No.4 April 2013

Zhou, M. \& Xu, H. (2012). A Review of Entrepreneurship Education for College Students in China. Administrative sciences, ISSN 2076-3387. 